\title{
Managerial Ability and Forecast Accuracy
}

\author{
Panagiotis I. Chronopoulos, Georgia Siougle \\ Athens University of Economics and Business, Greece
}

\begin{abstract}
We examine the relation between managerial ability and management forecast accuracy. We base our analysis on S\&P 500 Composite Index constituents for the period of 2006-2012. Data were collected from Thomson Reuteurs, Compustat and Demerjian, Lev, and McVay (2012). We find that forecast accuracy is positively associated with managerial ability in the case of sales forecasts. Specifically, more able managers are associated with lower magnitude's forecast errors in the case of sales forecasts. Additional analysis finds that managerial ability is immaterial to EPS figures' forecast accuracy, i.e., EPS forecasts appear not to be affected by manager's superiority. Regarding sales forecasts, the results are consistent with the assertion that managers impact the quality of the delivered management forecasts. Regarding EPS forecasts, the results are in alignment with Demerjian, Lev, Lewis, and McVay (2013) who highlighted that managerial ability is an ability score related to the entire management team.
\end{abstract}

Keywords: managerial ability, forecast accuracy, forecast error

\section{Introduction}

We examine the relation between managerial ability and forecast accuracy. We propose more able managers to be more knowledgeable of the business, to make better estimates and, thus, to provide more accurate forecasts. Our study bases on the results of Bertrand and Schoar (2003), who found that managers have an effect on firm choices such as acquisitions or R\&D expenditures; Aier, Comprix, Gunlock, and Lee (2005), who proposed that CFOs with more accounting expertise have fewer restatements; and Francis, Huang, Rajgopal, and Zang (2008), who documented that earnings quality relates negatively with CEO reputation.

We use as measure of managerial ability the score (MA-Score) that is developed by Demerjian et al. (2012). Demerjian et al. (2012) focused on revenue generation ability and initially estimated total firm efficiency, denoting that efficient firms are those that generate more revenues from a given set of assets (inputs). They supported that total firm efficiency is influenced by: (1) the manager, who can predict future demand and understand industry trends; and (2) the firm characteristics, because managers in larger firms can negotiate better terms. Demerjian et al. (2012) decomposed total firm efficiency into: (1) the efficiency stemming from the firm; and (2) the efficiency created by the manager. The results of Demerjian et al. (2012) verify that the efficiency component attributed to the manager is associated with a variety of characteristics, including managerial pay and the price reaction to management departures from the firm. Furthermore, previous research has narrowed the field of study on measures such as manager fixed effects. The results provide evidence of a manager-specific effect, but the quantifiable effect is limited to managers who switch firms (Bertrand \& Schoar, 2003; Ge, Matsumoto, \& Zhang, 2011). Contrary, the MA-Score allows isolating the efficiency effect of the manager from that of the firm, and delivers an ordinal ranking of managerial quality.

Panagiotis I. Chronopoulos, Ph.D., Department of Accounting and Finance, School of Business, Athens University of Economics and Business. Email: phronopoulos@aueb.gr.

Georgia Siougle, Associate Professor, Department of Accounting and Finance, School of Business, Athens University of Economics and Business. 
In alignment with Demerjian et al. (2012), we expect a more able management team to estimate accounting figures, related to firm efficiency and expansion, more accurately. In other words, we expect superior managers, firstly to be more knowledgeable of their client base, the macro-economic conditions and the future benefits of the assets involved when estimating sales figures. As additional analysis, we examine the impact of managerial ability on EPS forecasts, under the scope of Demerjian et al.'s (2012) comment that firm efficiency is a matter of corporate strategy, i.e., refers to the entire management team, and test if the conclusions derived for the sales forecasts hold for the EPS forecasts.

Our study contributes to the forecasting literature by presenting a positive and significant relation between managerial ability and forecast accuracy for sales figures. Further, based on the additional analysis, our study highlights that EPS forecast accuracy is not affected by manager's ability score. Regarding sales forecasts, our intuition promotes that it may not be necessary to affect forecast efficiency by applying emphasis on external factors' impact (firm size, industry, competition, and market exposure). In contrast, given the set of asset -liability business function resulting from the firm's business model, superior managers will be able to better deal with these complexities and provide more accurate forecasts relative to lower ability managers running similar firms operating in similar environments. Our finding is important for managers because managerial ability affects, besides the firm operations, the accuracy of the estimated figures and, in turn, firm's share-price behavior and its penalty/litigation exposure in case of misleading forecasts.

In Section 2, we develop the hypothesis and review the relevant literature. In Section 3, we describe the sample, test variables, and provide descriptive statistics. In Section 4, we describe our research design and in Section 5, we present our results and conduct additional analysis. We conclude the study in Section 6.

\section{Related Literature and Hypothesis Development}

\section{Managerial Ability}

Regarding the impact of managers on the firm, research has focused on several aspects of the issue. First, Bertrand and Schoar (2003) dealt with the matter of managers' ranking within deciles. They identified top managers across industries and confirmed that manager fixed effects accounted for significant variation in corporate investment, financial, operational strategies and policies. Their study forced research to concentrate on observable CEO characteristics, such as education, personal investment style, and gender. As a result, a growing literature that examines the impact of managers on several corporate aspects emerged since then. Specifically, Benmelech and Frydman (2015) examined managers' investment policy; Pan, Wang, and Weisbach (2014) examined managers' financial policy; Adams, Almeida, and Ferreira (2005) studied the impact of managers on firm performance; Chemmanur and Paeglis (2005) dealt with the examination of IPO's under the scope of different manager styles.

Furthermore, there is emerging literature that deals with more specific issues, and particularly, accounting issues. Dyreng, Hanlon, and Maydew (2010) and Koester, Shevlin, and Wangerin (2016) examined the manager impact on the corporate tax policy. Krishnan and Wang (2015) set the issue of auditor selection, and finally the most analytic field examines the relation of accounting choices and manager in control (Bamber, Jiang, \& Wang, 2010; DeJong \& Ling, 2010; Ge et al., 2011; Demerjian et al., 2013; Demerjian, Lewis, \& McVay, 2016). 
More analytically, regarding the core accounting related literature, Bamber et al. (2010) identified different manager styles which may appear under the scope of the propensity to issue guidance and the characteristics of the guidance (i.e., precision). Towards the same direction are the results of Ge et al. (2011) and DeJong and Ling (2010) who examined manager fixed effects on certain financial reporting policies. Evidence is provided on the field that firms' accounting and disclosure policies vary with manager fixed effects. DeJong and Ling (2010) investigated whether top executives have significant individual-specific effects on accruals beyond the amount explained from firm characteristics. They provided evidence that CEOs are more likely to affect accruals through firm policy decisions and CFOs are more likely to affect accruals through accounting decisions. Ge et al. (2011) examined whether accounting choices are influenced by differences in CFOs' individual characteristics due to several factors such as CFO's dispositions, personal situations and prior experiences. Their results suggest that the CFO-specific factors are a statistically significant determinant of accounting choices, and highlight the significance of adding CFO fixed effects to accounting data base models. Demerjian et al. (2013) examined earnings quality in terms of differing levels of manager ability and presented a positive association, denoting that more able managers present fewer restatements, higher accounting figure's persistence and more accurate bad debt provisions. Finally, Demerjian et al. (2016) investigated whether higher-quality managers are more likely to undertake earnings management mechanisms to artificially smooth earnings. Their results document a significant difference between better and worse managers. Specifically, they conclude that the best managers artificially smooth earnings to benefit shareholders in contrast to the worst managers who face smoothing constraints by corporate governance.

Our contribution to this growing literature is to provide evidence regarding the effect of managerial ability on the credibility of management forecasts. We foresee to highlight that behind the aforementioned accounting related styles and differences, there is also analogous style impact on the manager's forecasting accuracy.

\section{Management Forecast Accuracy}

Management earnings forecasts are referenced to be of higher value than the earnings figures themselves (Beaver, Cornell, Landsman, \& Stubben, 2008). Management forecast accuracy and forecast revision are mentioned among the most influential factors for the capital market when forming its expectations (Somnath, Kyonghee, \& Sukesh, 2012). Previous research has identified several factors affecting the magnitude of forecast error. More specifically, Brown and Higgins (2001) highlighted firm size, growth and the sign of forecast error as material factors affecting managers' forecasting activity and operating as constraints for their estimates to be delivered in public. Further, Matsumoto (2002) identified institutional ownership as a significant factor related to the magnitude of forecast errors. Richardson, Teoh, and Wysocki (2004) provided evidence that managers who engage in walk down expectations game have significant capital market incentives related to the issuance or selling of stock. Finally, Gong, Li, and Xie (2009) examined managers' optimistic bias and its effect on forecast accuracy. Their results present a significant and positive association between forecast errors and prior year's accruals. Gujon et al.'s (2009) intuition is that since a manager inserts optimistic bias into the accounting figures, analogous bias is expected to apply during the estimation of EPS forecast. As a result, there is confirmed larger forecast error in the year end.

\section{Hypothesis Development}

We assert managerial ability as a crucial factor influencing whether manager's forecasts are informative estimations or naïve expectations. We propose that more able managers to utilize in greater degree their access to vital internal information, according to which they draw analogous action plans and implement growth strategies. Such information refers to corporate strengths and weaknesses, which play a crucial role during the strategic 
decision process. Thus, we expect managers who present a higher level of managerial ability to acquire a more in-depth analysis of company's internal environment relative to the lower level managers. Additionally, we expect a superior manager to behave professionally and to estimate the forecasted figure after great in-depth analysis, in order to serve her manner for enhancing firm's accounting figures' information content. We expect that all the aforementioned high-end analytic procedures of estimating the forecasted figure to provide managers with a more in-depth knowledge of firm's deficiencies and weaknesses, leading to more accurate forecasts in the end.

We assert that firm efficiency under the scope of revenue generation (Demerjian et al., 2012) is indicative of manager's ability to create revenues acting under a strict and specific strategic plan. We expect a manager who is conscious with firm's short-term business expansion plan to be able to estimate with greater accuracy the level of firm's future sales. Furthermore, the utilization of available resources is efficiently achieved when it leads to business expansion through new markets' opening, customer base widening, i.e., outcomes that result in revenues to grow. Under this view of relating efficient resource utilization with firm growth and generation of revenues, we expect high levels of managerial ability to imply effect on the projection of future sales figures. This is because, a superior manager would achieve persistent growth rather than a bubble boost, making the relevant figures (sales) more predictable, i.e., minimizing the magnitude of committed forecast errors. Thus, we expect a manager's forecasting accuracy to vary with the levels of managerial ability. We form our hypothesis H1:

H1: Managerial ability is associated with management forecast errors.

\section{Data, Variables and Descriptive Statistics}

\section{Data}

We obtain managerial ability dataset, made available by Demerjian et al. (2012) ${ }^{1}$. We collect historical accounting data from Compustat. Management forecasting data were hand collected from Thomson Reuters. We focus on firms with managerial ability data and at least one EPS or sales forecast. Our sample contains observations of companies listed in the S\&P 500 Composite Index for the years of 2006-2012. We started with all firms listed in S\&P 500 Composite Index that have available forecasting and historical data within the period of 2006-2012. We require sufficient data availability to calculate accruals and control variables as well. We exclude from our sample financial, utilities and real estate industry classification codes. We further exclude from our sample firms that changed their capital with share distribution programs. Our initial sample consists of 945 firm year observations where either EPS or sales forecasting activity is evident.

\section{Variable Definition}

Our main set of control variables is based on the firm-specific determinants of forecast accuracy noted in previous literature (Brown \& Higgins, 2001; Matsumoto, 2002; Richardson et al., 2004; Gong et al., 2009). Specifically, firm size (Size), growth (Growth), prior year's accruals (TA), leverage (Leverage), institutional ownership (Inst) and stock's market behavior (Momentum) are set explanatory variables in our analysis, besides managerial ability variable (MAindex). Furthermore, we calculate and insert as explanatory variables the intra-year change of accounts receivable (dReceivables) and capital expenditures ( $d P P E)$, in order to capture any firm growth signs related to customer base widening and investments, respectively. Regarding the effect of share distribution, we controlled by excluding from our sample firms with changes in share capital. Table 1 provides variable definitions for all variables included in our analysis.

${ }^{1}$ Data were downloaded from http://faculty.washington.edu/pdemerj/data.html. 
Table 1

Definition of Variables

\begin{tabular}{|l|l|}
\hline Variable & Definition \\
\hline AFE & Analyst earnings forecast error \\
\hline AFE_S & Analyst sales forecast error \\
\hline CFO & Operating cash flows \\
\hline Momentum & Current year's stock cumulative returns on a 12-month basis \\
\hline Growth & Book-to-market ratio calculated as BV/MV \\
\hline Inst & Institutional ownership calculated as the percentage of shares held by institutional investors \\
\hline Leverage & Debt-to-equity ratio calculated as total debt/equity \\
\hline MAindex & Managerial ability measure as provided by Demerjian et al. $(2012)$ \\
\hline MFE & Manager earnings forecast error \\
\hline MFE_S & Manager sales forecast error \\
\hline dPPE & The current year change in PPE net calculated as PPE $E_{t}-P P E_{t-1}$ scaled by total assets \\
\hline dReceivables & $\begin{array}{l}\text { The current year change in receivables net of bad debt calculated as Receivables }- \text { Receivables }_{t-1} \\
\text { scaled by total assets }\end{array}$ \\
\hline Size & Natural logarithm of total sales \\
\hline TA & Total accruals calculated as net income $(N I)$ minus operating cash flow $(C F O)$ \\
\hline
\end{tabular}

\section{Descriptive Statistics}

For each of the variables, we present the basic descriptive statistics in Table 2. Management sales forecasts (MFE_S) are presented less accurate, with a mean of 0.0514006 and a standard deviation at 0.2147178 , contrary to the management EPS forecasts (MFE) with a mean at 0.0245581 and a standard deviation at 0.0771727. Further, managerial ability (MAindex) has a mean and median close to 0 , as it is calculated as a residual (Demerjian et al., 2012). Prior year's accruals (TA) are calculated at about $4 \%$ for both the values of mean and median. Finally, analyst EPS forecast error (AFE) mean is calculated at 0.0091752 and the median at 0.0076965 , and analyst sales forecast error (AFE_S) mean and median are calculated at 0.002052 and -0.0023709 respectively.

Table 2

Descriptive Statistics of All Variables Included in Analysis

\begin{tabular}{lllllll}
\hline Variable & $n$ & Mean & Median & SD & p25 & p75 \\
\hline AFE & 945 & 0.0091752 & 0.0076965 & 0.1083677 & -0.0021442 & 0.0211277 \\
AFE_S & 945 & 0.002052 & -0.0023709 & 0.1885553 & -0.010026 & 0.0033678 \\
CFO & 945 & 0.133406 & 0.1236667 & 0.0699877 & 0.086013 & 0.1702105 \\
dPPE & 945 & 0.0001433 & -0.0019497 & 0.1844511 & -0.0245936 & 0.0204782 \\
dReceivables & 945 & -0.0001144 & -0.001413 & 0.0853571 & -0.0158458 & 0.0088481 \\
Growth & 945 & 0.8930506 & 0.1013 & 4.092458 & 0.0523003 & 0.2135518 \\
Leverage & 945 & 0.6089059 & 0.6056693 & 0.298592 & 0.4746214 & 0.7160043 \\
Inst & 945 & 0.6642737 & 0.6735478 & 0.0571874 & 0.6172724 & 0.7150118 \\
MAindex & 945 & 0.008418 & 0.0020198 & 0.1483993 & -0.0718366 & 0.0778577 \\
MFE & 945 & 0.0245581 & 0.0146748 & 0.0771727 & 0.003336 & 0.0297714 \\
MFE_S & 945 & 0.0514006 & 0.0082771 & 0.2147178 & 0.0026556 & 0.0304221 \\
Momentum & 945 & 0.1084233 & 0.0976888 & 0.4042544 & -0.1160506 & 0.2982785 \\
Size & 945 & 2.212078 & 2.213125 & 0.1279575 & 2.127063 & 2.299096 \\
TA & 945 & -0.0422275 & -0.0449972 & 0.0710384 & -0.0745684 & -0.0142203 \\
\hline
\end{tabular}

Notes. ${ }^{* * *}$, and ${ }^{* * *}$ indicate significance at $10 \%, 5 \%$, and $1 \%$ (two-tailed). The sample consists of firm year observations during the period of 2006-2012 for firms listed in S\&P 500 Composite, meeting the sample selection criteria. 
In Table 3, we categorize our forecast accuracy measures and the rest control variables by managerial ability (MAindex). We denote low-quality (high-quality) managers as those in the bottom (top) quintile of managerial ability. We form quintiles by industry-year following (Demerjian et al., 2012). Forecast errors (MFE, MFE_S) are higher among low quality managers, consistent with our expectations. Nevertheless, the aforementioned negative relation is statistically significant only in the case of sales forecasts (MFE_S), whereas the EPS forecast error's magnitude is calculated insignificantly different between the upper and lower deciles, at $10 \%$.

Table 3

Forecast Accuracy by Managerial Ability

\begin{tabular}{|c|c|c|c|}
\hline Variable & $\begin{array}{l}\text { Lowest quintile of } \\
\text { managerial ability }\end{array}$ & $\begin{array}{l}\text { Highest quintile of } \\
\text { managerial ability }\end{array}$ & $\begin{array}{l}t \text {-test of difference } \\
\text { between the means }\end{array}$ \\
\hline$A F E$ & 0.0053935 & 0.0114093 & $1.6808^{*}$ \\
\hline AFE_S & 0.0234713 & 0.016681 & 1.1127 \\
\hline CFO & 0.1137753 & 0.1731772 & $-5.0700^{* * *}$ \\
\hline$d P P E$ & 0.0016829 & -0.0011135 & $2.1055^{* *}$ \\
\hline dReceivables & -0.020172 & 0.010535 & $-2.4671^{* *}$ \\
\hline Growth & 1.074729 & 1.163417 & $2.1184^{* * *}$ \\
\hline Inst & 0.6619894 & 0.6709026 & -1.0470 \\
\hline Leverage & 0.5622675 & 0.5465985 & 0.4643 \\
\hline MAindex & -0.2625854 & 0.2919529 & $-46.5184^{* * *}$ \\
\hline MFE & 0.0314469 & 0.0204926 & 1.5145 \\
\hline$M F E \_S$ & 0.0360615 & 0.0215276 & $2.5659^{* *}$ \\
\hline Momentum & 0.0380923 & 0.106681 & -1.0654 \\
\hline Size & 2.232732 & 2.186177 & $2.0225^{* *}$ \\
\hline$T A$ & -0.0347091 & -0.0539589 & $1.9711^{*}$ \\
\hline
\end{tabular}

Notes. ", , and " indicate significance at 10\%, 5\%, and 1\% (two-tailed). The sample consists of firm year observations during the period of 2006-2012 for firms listed in S\&P 500 Composite, meeting the sample selection criteria.

The control variables appear to differ significantly as well, towards the direction of supporting differing qualitative and quantitative characteristics between higher and lower ability managers. More specifically, in order to calculate differences in forecast error magnitude, we use the absolute values for intra-deciles comparisons. The absolute EPS forecast error (MFE) presents a mean of 0.0314469 for the lower and a mean of 0.0204926 for the upper deciles respectively. Absolute sales forecast error (MFE_S) presents a mean of 0.0360615 for the lower and a mean of 0.0215276 for the upper deciles. The calculated mean values differ at $5 \%$ level of significance only in the case of sales forecasts, though. Further, prior year's total accruals (TA) present a mean of -0.0347091 for the lower deciles and a mean of -0.0539589 for the upper deciles. The calculated mean values differ at $5 \%$ level of significance. With the exception of leverage, analogous picture holds for the rest of the control variables. Analyst EPS forecast error (AFE) is calculated in absolute terms at 0.0053935 for the lowest managerial ability decile and at 0.0114093 for the highest managerial ability decile and the difference is statistically significant at the $10 \%$ level. Contrary, analyst absolute sales forecast error (AFE_S) is calculated at 0.0234713 for the lowest managerial ability and at 0.016681 for the highest managerial ability without statistically significant difference between the deciles. Mean values for size and growth differ significantly at the $5 \%$ and $1 \%$ levels, respectively. 
According to the results of Table 3, a negative association between management forecast errors for EPS (MFE), sales (MFE_S) and managerial ability (MAindex) is evident, in alignment with our expectations. Further, we observe a negative association between managerial ability and prior year's accruals (TA), according to previous literature findings (Francis et al., 2008; Demerjian et al., 2013). Growth association with managerial ability (MAindex) is positive denoting the growth effect of superior managers' on the firm by more effective utilization of corporate resources. Finally, dReceivables and $d P P E$ variables denote that more able managers achieve a wider customer base (dReceivables $>0)$ with lower capital investments $(d P P E<0)$, i.e., additional evidence which presents the efficient resource allocation.

\section{Research Design}

Our research question is whether management forecast accuracy is affected by managerial ability. In order to perform our empirical analysis, we therefore need a quantitative measure of managerial ability. We draw from prior literature (Gong et al., 2009; Demerjian et al., 2012) for the test model.

\section{Managerial Ability Measure}

We adopt the measure developed by Demerjian et al. (2012) as the primary measure of managerial ability. According to Demerjian et al. (2012), a two-stage model is proposed. In the first stage, they modeled revenues as a function of revenue-generating resources (cost of inventory, general and administrative expenses, fixed assets, operating leases, past research and development expenditures, and intangible assets) in order to derive total firm efficiency of a firm relative to its industry rivals. In the second stage, Demerjian et al. (2012) decomposed total firm efficiency by regressing it on firm characteristics (firm size, market competition, cash resources available). Demerjian et al. (2012) asserted that, regardless of managerial ability, a manager is benefited from the size, the market share, and the liquidity. Whereas, the issues of diversification and strategic allocation of resources, operate as the field where managerial challenge bases on. More analytically, Demerjian et al. (2012) estimated the following Tobit model by industry:

$$
\begin{aligned}
\text { Firm Efficiency }_{i, t} & =a_{0}+a_{1} \ln \text { Total Assets } \\
i, t & +a_{2} \text { Market Share }_{i, t}+a_{3} \text { FCF indicator }_{i, t} \\
+a_{4} \ln \text { Age }_{i, t} & +a_{5} \text { Business Concentration }_{i, t}+a_{6} \text { Currency Indicator }_{i, t}+u_{i, t}
\end{aligned}
$$

The residuals from the model are retained as the measure of managerial ability (MAindex). According to the results (Demerjian et al., 2012), each coefficient obtains its predicted sign with statistical significance at the $5 \%$ or $1 \%$ level. Moreover, the residuals from the model (MA measure) are significantly correlated with alternative measures of managerial ability employed in prior research including historical industry-adjusted stock returns, historical industry-adjusted ROA, CEO compensation, and CEO tenure. In order to further support the results, Demerjian et al. (2012) validated MA measure alternatively: (1) they confirm that the MA measure is significantly and economically correlated with manager fixed effects; (2) they report evidence that the MA measure is negatively associated with announcement returns to CEO turnovers; (3) they demonstrate that appointing a relatively more (less) able manager, according to the MA measure, is systematically associated with positive (negative) changes in future firm performance. Nevertheless, Demerjian et al. (2013), when examining the relation between managerial ability and earnings quality, recognized as study's limitation the fact that earnings quality is more an accounting issue, thus a matter of Chief Financial Officer's treatment, rather a decision of Chief Executive Oficcer whose ability is measured by MA-score. 


\section{Forecast Accuracy Model for Sales}

In order to examine the managerial ability's impact on sales forecasts accuracy, we test the following model:

$$
\begin{aligned}
& \text { MFE_S } S_{i, t+1}=b_{0}+b_{1} \text { MAscore }_{i, t}+b_{2} \text { AFE_ } S_{i, t}+b_{3} \text { Size }_{i, t}+b_{4} \text { Leverage }_{i, t} \\
& +b_{5} \text { dReceivables }_{i, t}+b_{6} \text { CFO }_{i, t}+b_{7} d P P E_{i, t}+b_{8} \text { Inst }_{i, t}+b_{9} \text { Growth }_{i, t}+e_{i, t}
\end{aligned}
$$

We introduce as dependent variable the value of management sales forecast error (MFE_S) in year $t+1$. Our key explanatory variable of interest is the managerial ability (MAindex). We exclude accruals from our analysis, since sales figures account for the basic component of accrual in earnings. Further, we introduce a set of control variables that are expected to influence sales forecast error's magnitude. As such, we assert analysts' sales forecast error (AFE_S), firms' size (Size), leverage (Leverage), the intra-year change in accounts receivables (dReceivables) and property, plant and equipment (dPPE), operating cash flows (CFO), and institutional ownership (Inst). We exclude growth from the set of explanatory variables since sales growth accounts for an alternative way to measure firm rate of expansion. All the control variables are estimated based on the previous year's accounting figures $(t=0)$. We, again, control the model for year and industry fixed effects.

With this research design, we attempt to capture manager's improvement in sales forecast accuracy in the case he/she presents a higher level of ability to utilize the available corporate resources for the benefit of sales, contrary to the case he/she presents a lower level of managerial ability. If H1 holds, we expect managerial ability (MAindex) to be a statistically significant estimator of management sales forecast error (MFE_S), i.e., $b_{1} \neq 0$. We further expect a negative $\left(b_{1}<0\right)$ coefficient under the assumption that manager of higher ability (MAindex) being more analytic and concentrated to detail, performs better estimations that eventually prove to be more accurate, regarding corporate expansion and growth figures, i.e., sales.

\section{Empirical Findings}

\section{Managerial Ability and Forecast Accuracy}

We examine the effect of manager's ability to efficiently utilize corporate resources, under the scope of his ability to generate more reliable and accurate forecasts of sales. We test whether the managerial ability variable (MAindex) operates as a significant explanatory variable for the current year's sales absolute forecast error. Table 4 presents the estimated model coefficients for the MFE_S model (H1). The assertion behind our analysis is that the manager, who presents high levels of managerial ability, applies analytic procedure in more depth. As a result, the manager is expected to acquire better knowledge of the firm innate and external environment, in a direction of self-improvement, regarding the prediction of future business outcomes. Sales are asserted to mainly mirror firm expansion and growth, since the opening of new markets, the cross-country trading and the wide customer base, are all supposed to end in sales boosting, eventually. Thus, a manager's high level of ability to understand business strengths and weaknesses, to combine efficiently the corporate resources and to allocate economically the financing choices, is expected to eventually lead in sales figure's growth. We support that as manager is able to apply successful business strategy, she is in the position to better estimate and predict the future sales figures, relative to a manager who is of lower ability, i.e., commits sales forecast errors of greater magnitude. 
Table 4

Testing the Managerial Ability on Sales Forecast Accuracy (Regressions of Management Absolute Sales Forecast Errors on Managerial Ability (MAindex), Analyst Forecast Error (AFE_S) and a Set of Control Variables: $M F E \_S_{i, t+1}=b_{0}+b_{1}$ MAscore $_{i, t}+b_{2}$ AFE_S $S_{i, t}+b_{3}$ Size $_{i, t}+b_{4}$ Leverage $_{i, t}+b_{5}$ dReceivables $_{i, t}+b_{6}$ CFO $_{i, t}$ $+b_{7} d P P E_{i, t}+b_{8}$ Inst $_{i, t}+b_{9}$ Growth $\left._{i, t}+e_{i, t}\right)$

\begin{tabular}{|c|c|}
\hline Variable & Coefficient \\
\hline Intercept & $\begin{array}{l}0.530186^{* * *} \\
(2.54)\end{array}$ \\
\hline MAindex & $\begin{array}{l}-0.1560002^{* *} \\
(-2.26)\end{array}$ \\
\hline$A F E \_S$ & $\begin{array}{l}0.0108559 \\
(0.40)\end{array}$ \\
\hline Size & $\begin{array}{l}-0.0092267 \\
(-0.47) \\
\end{array}$ \\
\hline Leverage & $\begin{array}{l}0.0099443 \\
(0.60)\end{array}$ \\
\hline dReceivables & $\begin{array}{l}-0.0285282 \\
(-0.72)\end{array}$ \\
\hline $\mathrm{CFO}$ & $\begin{array}{l}-0.1594916^{*} \\
(-1.73)\end{array}$ \\
\hline$d P P E$ & $\begin{array}{l}-0.0371408^{* * *} \\
(-2.74)\end{array}$ \\
\hline Inst & $\begin{array}{l}0.0411093 \\
(0.31) \\
\end{array}$ \\
\hline Growth & $\begin{array}{l}0.0012317^{* * *} \\
(3.40)\end{array}$ \\
\hline Fixed effects & Year \& industry \\
\hline Adjusted $R^{2}$ & 0.0546 \\
\hline Observations & 942 \\
\hline
\end{tabular}

Notes. ${ }^{* * *}$, and ${ }^{* * * *}$ indicate significance at $10 \%, 5 \%$, and 1\% (two-tailed). $t$-statistics in parentheses are based on robust standard errors. The sample consists of observations during the period of 2006-2012 for firms listed in S\&P 500 Composite meeting the sample selection criteria. Variables are defined as: MAindex is obtained from publicly available data provided by Demerjian et al. (2012); AFE_S is analyst sales forecast error; Size is logarithm of sales; Leverage is debt-to-equity ratio; dReceivables is the current year change in receivables net of bad debt calculated as Receivables Receivables $_{t-1}$ scaled by total assets; CFO is operating cash flows; $d P P E$ is the current year change in PPE net calculated as $P P E_{t}-P P E_{t-1}$ scaled by total assets; Inst is calculated as the percentage of shares held by institutional investors; and Growth is book-to-market ratio calculated as BV/MV.

The coefficient of managerial ability variable (MAindex) is estimated negative and statistically significant $(-0.1560002, t=-2.26)$, confirming H1. A higher ability manager, besides being capable of more efficient business running, proves to be an accurate forecaster, as well, contrary to a lower ability manager. Sales accounting figure is not susceptible to CFO's decisions and ability to implement accounting standards, and thus overall CEO ability for corporate expansion and efficiency appears to associate with the future sales. A superior manager achieves stable sales growth making sales figure more predictable and sales forecasts less inaccurate. Analyst sales forecast error (AFE_S) is calculated statistically insignificant. Analysts' forecasts appear not crucial in the estimation of management sales forecasts. Leverage expressing the business risk the manager faces from the combination of private and foreign capital resources is also positively related, as expected. The rest control variables, operating cash flows $(C F O)$ and Growth are estimated with negative $(-0.1594916$, $t=-1.73)$ and positive $(0.0012317, t=3.40)$ coefficients, statistically significant at the $10 \%$ and $1 \%$ levels, respectively. 


\section{Additional Analysis: Managerial Ability and EPS Forecast Accuracy}

Since we presented a positive and significant relation between managerial ability and sales forecast accuracy, we extend our analysis on the EPS forecast accuracy. We recognize that sales figures do not share the same estimation criteria and standards as EPS figures, in alignment with Demerjan et al. (2012) who referred to the MA-score as an entire management team related measure. More analytically, we expect accounting figures which are susceptible to accounting standards and measurements, to be outside top management team's scope of influence. We recognize that EPS figures are susceptible to the understanding and application of complex accounting standards, based on which income is determined and reported (McNichols, 2002). Thus, managerial ability, which is calculated for the management team, is expected to be irrelevant to the EPS figures' estimation.

In order to test the managerial ability differing levels on the EPS forecast accuracy, we apply analogous methodology as for H1. Regarding manager's forecast accuracy for the years that either EPS or sales management forecast is provided; we create forecast error models for EPS management forecasts. We build on previous research (Gong et al., 2009) findings and assertions, and extend our research field with the examination of managerial ability. Specifically, we follow Gong et al. (2009) and test the following forecast accuracy model for EPS:

$$
\begin{aligned}
\text { MFE }_{i, t+1}= & a_{0}+a_{1} \text { MAscore }_{i, t}+a_{2} \text { TA }_{i, t}+a_{3} \text { AFE }_{i, t}+a_{4} \text { Size }_{i, t}+a_{5} \text { Growth }_{i, t} \\
& +a_{6} \text { Leverage }_{i, t}+a_{7} \text { Inst }_{i, t}+a_{8} \text { Momentum }_{i, t}+u_{i, t}
\end{aligned}
$$

We introduce as dependent variable the absolute value of management earnings forecast error (MFE) in year $t+1$. Our key explanatory variables of interest are the managerial ability (MAindex) as estimated and provided for research from Demerjian et al. (2012) and the historical accruals (TA) in year $t=0$. Apart from the variables of main interest, we introduce a number of control variables that are expected to influence earnings forecast error's magnitude. As such, we assert analysts' EPS forecast error (AFE), firms' growth (Growth), size (Size), leverage (Leverage), institutional ownership (Inst) and financial market variability (Momentum). All the control variables are estimated based on the previous year's accounting figures ( $t=0$, point A). We further control the model for year and industry fixed effects.

We assert that Gong et al. (2009) documented optimistic bias to be less apparent due to the more extensive analytic procedure, in the cases where manager presents high levels of managing ability. Thus, we expect superior managers to commit lower forecast errors, compared to the lower levels' managers. If our assertions hold, we expect the variable presenting the manager's ability calculated based on previous year's accrual figures, i.e., managerial ability (MAindex), to be a statistically not significant estimator of management earnings forecast error (MFE), i.e., $a_{1}=0$.

Table 5 presents the estimated model coefficients for the MFE model. We test whether the managerial ability variable (MAindex) operates as a significant explanatory variable for the current year's EPS forecast error. The assertion behind our analysis is that since managerial ability variable (MAindex) measures, in fact, manager's ability to efficiently utilize available corporate and financing resources, we expect it not to relate with matters of accounting standards, based on which accounting figures and especially EPS are determined and presented. As a result, we propose that EPS figure is more a matter of presentation rather than a matter of corporate effectiveness and expansion. Thus, we expect managerial ability to be irrelevant to the issue of EPS forecast accuracy, for a firm. 
Table 5

Testing the Managerial Ability on EPS Forecast Accuracy (Regressions of Management Absolute EPS Forecast Errors on Managerial Ability (MAindex), Historical Accruals (TA), Analyst Forecast Error (AFE) and a Set of Control Variables: MFE $_{i, t+1}=a_{0}+a_{1}$ MAscore $_{i, t}+a_{2}$ TA $_{i, t}+a_{3} A F E_{i, t}+a_{4}$ Size $_{i, t}+a_{5}$ Growth $_{i, t}+a_{6}$ Leverage $_{i, t}+$ $a_{7}$ Inst $_{i, t}+a_{8}$ Momentum $\left._{i, t}+u_{i, t}\right)$

\begin{tabular}{ll}
\hline Variable & Coefficient \\
\hline Intercept & $0.0627127^{* * *}$ \\
& $(2.83)$ \\
\hline \multirow{2}{*}{ MAindex } & -0.0097234 \\
& $(-1.26)$ \\
\hline \multirow{2}{*}{ TA } & $0.0751658^{* *}$ \\
& $(2.24)$ \\
\hline \multirow{2}{*}{ AFE } & $0.2716367^{* * *}$ \\
& $(3.80)$ \\
\hline \multirow{2}{*}{ Size } & $-0.0218877^{* *}$ \\
& $(-2.27)$ \\
\hline \multirow{2}{*}{ Growth } & $0.0023442^{* * *}$ \\
\hline \multirow{2}{*}{ Leverage } & $(13.63)$ \\
\hline \multirow{2}{*}{ Inst } & 0.0021048 \\
& $(0.39)$ \\
\hline \multirow{2}{*}{ Momentum } & 0.001665 \\
& $(0.08)$ \\
\hline
\end{tabular}

Fixed effects $\quad$ Year \& industry

Adjusted $R^{2} \quad 0.4681$

Observations 946

Notes. ", and " indicate significance at 10\%, 5\%, and 1\% (two-tailed). $t$-statistics in parentheses are based on robust standard errors. The sample consists of observations during the period of 2006-2012 for firms listed in S\&P 500 Composite meeting the sample selection criteria. Variables are defined as: MAindex is obtained from publicly available data provided by Demerjian et al. (2012); TA is absolute total accruals calculated as net income (NI) minus operating cash flow (CFO); AFE is analyst EPS forecast error; Size is logarithm of sales; Growth is book-to-market ratio; Leverage is debt-to-equity ratio; Inst is calculated as the percentage of shares held by institutional investors; financial market conditions Momentum is current year's stock cumulative returns.

The coefficient of managerial ability variable (MAindex) is estimated statistically insignificant, confirming our expectations. EPS accounting figure is susceptible to manager's decisions and ability to implement accounting standards, and thus overall manager ability for corporate expansion and efficiency appears to be irrelevant to EPS figure's estimation. The coefficient of historical accruals (TA) is calculated positive $(0.0751658, t=2.24)$ and statistically significant according to the expectation that managers' imperfect business assessment influences both accruals and earnings projection (Gong et al., 2009). Regarding the rest control variables, analyst EPS forecast error $(A F E)$ is the basic control variable affecting manager's forecast accuracy (positive relation), and leverage expressing the business risk the manager faces from the combination of private and foreign capital resources is also positively related, as expected. Finally, the financial market's conditions, i.e., Momentum coefficient is calculated positive but statistically insignificant at $10 \%$ level $(0.0052815, t=1.21)$.

The results provide evidence that sales and EPS forecasts share different motivation and strategic criteria, and as a result are susceptible to different degrees of influence form the manager. We document a differing strategy behind sales figure's estimation, as it is determined based on a realistic firm base rather on a theoretic measurement and application of accounting standards. 


\section{Conclusion}

Our empirical results contribute to a relatively new but growing literature documenting reporting effects of MA-score (Demerjian et al., 2013; Cornaggia, Krishnan, \& Wang, 2017). We extend this line of research to include forecasting activity. Specifically, we employ quantitative measure of managerial ability as a proxy for the manager's quality regarding the provision of accurate estimates and find statistically significant differing characteristics for the case of sales forecasts. Contrary, managerial ability appears immaterial for the determination of EPS forecasts, highlighting the great impact of accounting standards and regulation. Accounting conservatism appears to mitigate manager's high ability effect.

The managerial ability effect on manager forecasting activity is significant for investors and managers since it highlights the differing strategies behind the estimation of fundamentals, drawing useful implications for valuation and compensation matters. Overall, we conclude that managerial ability is relevant as a significant forecast accuracy factor in the estimation of sales. Our results further underscore the role of managers in EPS determination and thus create a potentially important valuation implication.

\section{References}

Adams, R., Almeida, H., \& Ferreira, D. (2005). Powerful CEOs and their impact on corporate performance. Review of Financial Studies, 18(4), 1403-1432.

Aier, J., Comprix, J., Gunlock, M., \& Lee, D. (2005). The financial expertise of CFOs and accounting restatements. Accounting Horizons, 19(3), 123-135.

Bamber, L., Jiang, J., \& Wang, I. (2010). What's my style? The influence of top managers on voluntary corporate financial disclosure. The Accounting Review, 85(4), 1131-1162.

Beaver, W., Cornell, B., Landsman, W. R., \& Stubben, S. R. (2008). The impact of analysts' forecast errors and forecast revisions on stock prices. Journal of Business Finance \& Accounting, 35(5-6), 709-740.

Benmelech, E., \& Frydman, C. (2015). Military CEOs. Journal of Financial Economics, 117(1), 43-59.

Bertrand, M., \& Schoar, A. (2003). Managing with style: The effect of managers on firm policies. The Quarterly Journal of Economics, 118(4), 1169-1208.

Brown, L. D., \& Higgins, H. N. (2001). Managing earnings surprises in the US versus 12 other countries. Journal of Accounting and Public Policy, 20(4-5), 373-398.

Chemmanur, T. J., \& Paeglis, I. (2005). Management quality, certification, and initial public offerings. Journal of Financial Economics, 76(2), 331-368.

Cornaggia, K. J., Krishnan, G. V., \& Wang, C. (2017). Managerial ability and credit ratings. Contemporary Accounting Research, 34(4), 2094-2122.

DeJong, D., \& Ling, Z. (2010). Managers: Their effects on accruals and firm policies. Working Paper, The University of Iowa.

Demerjian, P., Lev, B., \& McVay, S. (2012). Quantifying managerial ability: A new measure and validity tests. Management Science, 58(7), 1229-1248.

Demerjian, P., Lev, B., Lewis, M., \& McVay, S. (2013). Managerial ability and earnings quality. The Accounting Review, 88(2), 463-498.

Demerjian, P., Lewis, M., \& McVay, S. (2016). Earnings smoothing: For good or evil? Working Paper, University of Washington.

Dyreng, S. D., Hanlon, M., \& Maydew, E. L. (2010). The effects of executives on corporate tax avoidance. The Accounting Review, 85(4), 1163-1189.

Francis, J., Huang, A., Rajgopal, S., \& Zang, A. (2008). CEO reputation and earnings quality. Contemporary Accounting Research 25(1), 109-147.

Ge, W., Matsumoto, D., \& Zhang, J. (2011). Do CFOs have style? An empirical investigation of the effect of individual CFOs on accounting practices. Contemporary Accounting Research, 28(4), 1141-1179.

Gong, J., Li, Y., \& Xie, H. (2009). The association between management earnings forecast errors and accruals. The Accounting Review, 84(2), 497-530. 
Koester, A., Shevlin, T., \& Wangerin, D. (2016). The role of managerial ability in corporate tax avoidance. Management Science, 63(10), 3285-3310.

Krishnan, G., \& Wang, C. (2015). The relation between managerial ability and audit fees and going concern opinions. Auditing: A Journal of Practice and Theory, 34(3), 139-160.

Matsumoto, D. A. (2002). Management's incentives to avoid negative earnings surprises. The Accounting Review, 77(3), $483-514$.

McNichols, M. F. (2002). The quality of accruals and earnings: The role of accrual estimation errors: Discussion. The Accounting Review, 77(4), 61-69.

Pan, Y., Wang, T. Y., \& Weisbach, M. S. (2014). Does uncertainty about management affect firms' costs of borrowing? National Bureau of Economic Research Working Paper.

Richardson, S., Teoh, S. H., \& Wysocki, P. D. (2004). The walk-down to beatable analyst forecasts: The role of equity issuance and insider trading incentives. Contemporary Accounting Research, 21(4), 885-924.

Somnath, D., Kyonghee, K., \& Sukesh, P. (2012). On the anomalous stock price response to management earnings forecasts. Journal of Business Finance and Accounting, 39(7-8), 905-935. 